\title{
Phytotoxic Effect of Tithonia rotundifolia (Miller) S.F.Blake on Chlorophyll and Protein Contents of Vigna
}

\author{
unguiculata L. and Zea mays L.
}

\author{
Ilori Olasupo John (Corresponding author) \\ Department of Biological Sciences, Faculty of Natural and Applied Sciences, Anchor \\ University, Lagos, Nigeria, Email: oilori@aul.edu.ng or olasupoilori@yahoo.com \\ Olutobi Oluwafunmilayo Otusanya \\ Department of Biological Sciences, College of Natural and Applied Sciences \\ Wesley University, Ondo, Nigeria, Email: ootusan@yahoo.com
}

Received: May 4, 2019 Accepted: May 30, 2019

doi:10.5296/jbls.v10i2.14729 URL: https://doi.org/10.5296/jbls.v10i2.14729

\begin{abstract}
A large number of plants impose inhibitory effects on the germination and growth of neighbouring or successional plants by releasing allelochemicals into the soil. This study investigated the phytotoxic effects of Tithonia rotundifolia (Miller) S.F.Blake on the chlorophyll and protein contents of Vigna unguiculata (L.) Walpers and Zea mays L.. This was with a view to determining the susceptibility of these crops to allelochemicals in the extracts prepared from $T$. rotundifolia. Seeds of the test plants were sown in pots filled with top humus soil. At two weeks, seedlings in each pot were thinned down to 10 seedlings per pot. Potted plants of the test crops were supplied with $400 \mathrm{ml}$ of the appropriate water extracts while the control potted plants were supplied with $400 \mathrm{ml}$ of water. Biochemical analyses were carried out according to standard methods. The data obtained were analysed by (ANOVA) to determine significant $(\mathrm{P}<0.05)$ effects. The means were compared using Duncan Multiple Range Test. The chlorophyll a, chlorophyll b, total chlorophyll and protein contents in $V$. unguiculata and $Z$. mays and were significantly inhibited by the extract from $T$. rotundifolia. The inhibitory effects of these allelochemicals increased with concentration. The phytotoxic effect of $T$. rotundifolia was species dependent. It was concluded that the extract contains water-soluble allelochemicals which inhibited the biochemical parameters of the test crops. T. rotundifolia should be controlled where it grows in association with cultivated crops.
\end{abstract}

Keywords: phytotoxic, allelochemicals, Tithonia rotundifolia, water extracts, test crops 


\section{Introduction}

Tithonia rotundifolia (Miller) S.F. Blake is a members of the family Asteraceae. In Nigeria, $T$. rotundifolia have colonized roadsides, waste places, fallow land and disturbed open spaces like abandoned construction sites etc. displacing traditional weedy species like Chromolaena odorata and Panicum maximum (Adebowale and Olorode, 2005). According to Tongma, et al. (1998), the plant associates with common crops like vegetables, cassava, yam, rice, sorghum, soyabean e.t.c. and becomes a dominant plant where it is present.

Cowpea (Vigna unguiculata (L.) Walpers) which belong to the family Fabaceae is economically significant legumes in the tropics. $V$. unguiculata is a staple food for the majority of the world population. Its grains are consumed by man as cheap plant protein since fish, meat, milk and egg proteins are fast disappearing (Alabi et al., 2003). Maize (Zea mays L.) is an annual grass belonging to the family Poacea. Z. mays. is one of the most important cereal crops growing in the world. It is used as food for human consumption as well as food grain for animals (Moussa, 2001).

Siyar et al. (2017) reported that weed incursion in cultivated fields is a serious biological problem, which causes considerable yield losses of economically important field crops through allelopathy and competitive interactions. Allelopathic interactions are mediated by secondary metabolites (allelochemicals) released through leaching, root exudation, volatilization and residue decomposition into the environment and affect growth and development in natural environments and agro-ecosystems (Cheema et al. 2013). Allelochemicals may be distributed broadly among organs such as seeds, flowers, pollen, leaves, stems, and roots, or sometimes found in just one or two such locations Zeng et al. 2008).

Masuda et al. (2002) observed that allelochemicals could inhibit the enzyme protoporphyrinogen oxidase and therefore lead to alteration in chlorophyll biosynthesis. They further stated that allelochemical effects on photosynthesis could also be the result of an alteration in chlorophyll degradation pathway and inhibition of carotenoid biosynthesis Yang et al. (2002) observed that chlorophyll biosynthesis of rice seedlings was inhibited by exogenously applied allelochemicals. The authors asserted that chlorophyll reduction must result in a decrease of photosynthesis efficiency. They also suggested that higher concentration of allelochemicals would inhibit physiological activities the more Zarnota, et al. (2003) found that some allelochemicals have potential phytotoxic activity as photosystem II inhibitor since chlorophyll molecules are the core component of pigment - protein complexes embedded in the photosynthetic membranes.

According to Maysa and Salama, (2009), the germination, shoot and root length, dry weight, water content, chlorophyll content, proteins, carbohydrates and proline of Triticum Aestivum were significantly inhibited by increasing the concentration of allelochemicals extracted from Achillea santolina. Saeid et al. (2010) found that allelochemicals decreased the amount of protein in wheat seedlings. Hussain et al. (2010) reported that ferulic acid and p-hydroxybenzoic acid significantly reduced the leaf protein contents of Lactuca sativa. 
Considering the effects of Tithonia species on associated crops there is the need for studies on the allelopathic effects of this weed on important economic crop plants grown in Nigeria. Therefore, the objective of the research was to determine the effects of water extracts of fresh shoots of $T$. rotundifolia on the chlorophyll and protein accumulation of $V$. unguiculata and $Z$. mays

\section{Materials and Methods}

\subsection{Plant Materials and Extraction}

The seeds of Vigna unguiculata and Zea mays were collected from IITA (International Institute of Tropical Agriculture) Ibadan. T. rotundifolia seeds were collected Staff Quarter of Obafemi Awolowo University (O. A. U) Ile-Ife, Osun State, Nigeria. Plastic pots $(25 \mathrm{~cm}$ diameter $\mathrm{x} 22 \mathrm{~cm}$ height) with four holes perforated at the bottom for good drainage were filled almost to the brim with top humus soil. The seeds of $T$. rotundifolia were sown in each of the pots and watered with $400 \mathrm{ml}$ of tap water every morning. Extraction procedures was carried out according to the modified method of Qasem and Abu - Irmaileh (1985). Fresh plants of T.rotundifolia were harvested before flowering and separated into shoots and roots. $250 \mathrm{~g}$ of the fresh shoots were cut into small chips of about four centimeter lengths and finely ground with a mortar and pestle. The ground plant material was soaked in two litres of water for twelve hours. The solution was filtered through cheese cloth to remove debris and then filtered through Whatman No 1 filter paper. This extract solution (100\%) was diluted appropriately with water to give $75 \%, 50 \%$, and $25 \%$ concentrations of the aqueous extracts while distilled water served as control

\subsection{Experimental Design and Treatment}

Plastic pots (25 cm diameter x $22 \mathrm{~cm}$ height) with four holes perforated at the bottom for good drainage were filled almost to the brim with top humus soil. Seeds of the test plants were sown at equal distance in the pots and watered with $400 \mathrm{ml}$ of tap water every morning. At two weeks, seedlings in each pot were thinned down to 10 seedlings per pot. Thereafter, the pots in the control regime were supplied with water daily while the pots belonging to the different treatments were supplied with either the appropriate water extracts (100 FWE,75\% FWE 50\% FWE 25\% FWE) daily in same quantity. Treatments were arranged in a randomized complete block design with five replications.

\subsection{Determination of Chlorophyll and Protein Content}

Chlorophyll contents were determined using the method of Comb et al. (1985). Plants were separated into shoot and root and then chlorophyll was extracted from the shoot. The shoot was cut into small chips and placed in a mortar. A pinch of sodium bicarbonate was added to the shoot in the mortar to prevent degradation of chlorophyll to phaeophytin and then the shoot was then ground in $80 \%(\mathrm{v} / \mathrm{v})$ acetone. The brei was filtered through a Whaman No 1 filter paper and absorbance of the acetone filtrate was determined using a spectrophotometer at wavelength $647 \mathrm{~nm}$ and $664 \mathrm{~nm}$.

Chlorophyll a, chlorophyll $\mathrm{b}$ and total chlorophyll were determined using the formulae below. 
Chlorophyll a $=\quad 13.19 \mathrm{~A}_{664}-2.57 \mathrm{~A}_{647}(\mu \mathrm{g} / \mathrm{g})$

Chlorophyll $\mathrm{b}=22.10 \mathrm{~A}_{647-} 5.26 \mathrm{~A}_{664}(\mu \mathrm{g} / \mathrm{g})$

Total chlorophyll $=\quad 7.93 \mathrm{~A}_{644}+19.53 \mathrm{~A}_{647}(\mu \mathrm{g} / \mathrm{g})$

Where $\mathrm{A}_{647}$ is absorbance at $647 \mathrm{~nm}$ wavelength, $\mathrm{A}_{664}$ is absorbance at $664 \mathrm{~nm}$ wavelength

Total protein concentration was determined using the technique of Lowry et al. (1951).

\subsection{Statistical Analysis}

The results were analyzed statistically with the use of one-way analysis of variance (ANOVA) to determine significant $(\mathrm{P}<0.05)$ effects. The means were compared using Duncan Multiple Range Test (DMRT)

\section{Results}

Tables 1a \&1b show the effects of fresh shoot water extracts (FWE) of $T$. rotundifolia on $V$. unguiculata. Results indicated that chlorophyll a, chlorophyll $\mathrm{b}$, total chlorophyll in the control shoots of $V$. unguiculata were significantly different at $\mathrm{p}<0.05$ and higher than those of the shoot of seedlings treated with the different extracts throughout the period of the experiment. It was observed that the highest concentration 100\% FWE inhibited the total chlorophyll content by $27 \%$ while the $25 \%$ extract reduced the total chlorophyll by $13 \%$. The extent of the inhibition of chlorophyll a, chlorophyll $b$, total chlorophyll by these extracts was observed to follows this order $100 \%>75 \%>50 \%>25 \%$ i.e The allelopathic retardatory effect on chlorophyll contents observed were extract concentration dependent

The protein contents of the extract treated plants were significantly $(\mathrm{P}<0.05)$ lower than that of the control plants. The protein content decreased from $3.20(\mu \mathrm{g})$ in the control plants to $1.07(\mu \mathrm{g})$ in the plants treated with 100\% FWE. The $25 \%$ FWE treated plants had a protein content that was decreased by $13 \%$ when compared with the control plants. Protein content showed significant decrease by increasing the extract concentration. The effect of fresh shoot extracts of T. rotundifolia on Z. mays is shown in Tables $2 \mathrm{a} \& 2 \mathrm{~b}$. Chlorophyll a, chlorophyll $\mathrm{b}$ and total chlorophyll in the extracts treated Z. mays were significantly lower than that of the control plants. The total chlorophyll of the $100 \%$ FWE plants was reduced by $26 \%$ compared to the control plants. The potency of allelochemicals in the extracts was dependent on the concentration of the extracts in most cases. The extent of the inhibition of chlorophyll a, chlorophyll $\mathrm{b}$, total chlorophyll by these extracts was observed to follows this order $100 \%>75 \%>50 \%>25 \%$ i.e The allelopathic retardatory effect observed was extract concentration dependent. Protein content of the control plant was significantly $(\mathrm{P}<0.05)$ higher than those of $100 \%$ FWE. The plants treated with highest extract concentration $(100 \%)$ of $T$. totundifolia showed $42 \%$ decrease with respect to control. The protein contents of $Z$. mays in $75 \%$ FWE, $50 \%$ FWE and $25 \%$ FWE were not significantly different from that of the control. 


\section{1) Macrothink}

Table 1a. Effect of fresh shoot water extracts (FWE) of T. rotundifolia on chlorophyll a and chlorophyll b contents of $V$. unguiculata

\begin{tabular}{|c|c|c|c|}
\hline Chlorophyll a $(\mu \mathrm{g} / \mathrm{g})$ & Week 1 & Wewek2 & Week 3 \\
\hline Control & $381.00 \pm .32^{\mathrm{a}}$ & $410.60 \pm 3.03^{\mathrm{a}}$ & $480.47 \pm 1.60^{\mathrm{a}}$ \\
\hline $100 \%$ FWE & $200.32 \pm .81^{\mathrm{b}}$ & $301.12 \pm .97^{\mathrm{b}}$ & $310.03 \pm 2.73^{b}$ \\
\hline $75 \%$ FWE & $210.33 \pm .21^{\mathrm{c}}$ & $320.30 \pm .66^{c}$ & $340.20 \pm 2.10^{c}$ \\
\hline $50 \%$ FWE & $280.60 \pm 1.9^{d}$ & $348.90 \pm .84^{\mathrm{d}}$ & $399.24 \pm 4.33^{d}$ \\
\hline $25 \%$ FWE & $280.98 \pm 1.4^{\mathrm{d}}$ & $380.82 \pm 1.7^{\mathrm{e}}$ & $410.26 \pm 2.65^{\mathrm{e}}$ \\
\hline \multicolumn{4}{|l|}{ Chlorophyll b $(\mu \mathrm{g} / \mathrm{g})$} \\
\hline Control & $211.38 \pm .75^{\mathrm{a}}$ & $285.60 \pm 1.70^{\mathrm{a}}$ & $313.76 \pm 1.61^{\mathrm{a}}$ \\
\hline $100 \% \mathrm{FWE}$ & $80.31 \pm 1.24^{b}$ & $71.60 \pm .50^{b}$ & $199.47 \pm 3.03^{b}$ \\
\hline $75 \%$ FWE & $179.50 \pm .45^{\mathrm{c}}$ & $140.04 \pm .63^{c}$ & $251.26 \pm 2.26^{\mathrm{c}}$ \\
\hline $50 \%$ FWE & $184.40 \pm 1.21^{\mathrm{d}}$ & $241.20 \pm .48^{\mathrm{d}}$ & $281.46 \pm 6.47^{\mathrm{d}}$ \\
\hline $25 \% \mathrm{FWE}$ & $201.20 \pm 2.25^{\mathrm{e}}$ & $211.82 \pm 1.2^{\mathrm{e}}$ & $301.40 \pm 4.24^{\mathrm{e}}$ \\
\hline
\end{tabular}

FWE: Fresh shoot water extract treatment. Figures on the same column followed by different letters show significant differences with each other at $p<0.05$ according to DMRT 


\section{Macrothink}

Journal of Biology and Life Science ISSN 2157-6076 2019, Vol. 10, No. 2

Table 1b. Effect of fresh shoot water extracts (FWE) of T. rotundifolia on total chlorophyll and protein contents of $V$. unguiculata

\begin{tabular}{|c|c|c|c|}
\hline $\begin{array}{l}\text { Total Chlorophyll } \\
(\mu \mathrm{g} / \mathrm{g})\end{array}$ & Week 1 & Wewek2 & Week 3 \\
\hline Control & $579.10 \pm 5.46^{\mathrm{a}}$ & $673.20 \pm 2.20^{\mathrm{a}}$ & $846.69 \pm 1.58^{a}$ \\
\hline $100 \%$ FWE & $305.29 \pm .66^{b}$ & $384.80 \pm 2.57^{b}$ & $620.57 \pm 7.84^{b}$ \\
\hline $75 \%$ FWE & $387.74 \pm 6.51^{c}$ & $471.21 \pm 1.20^{\mathrm{c}}$ & $620.70 \pm 3.22^{b}$ \\
\hline $50 \%$ FWE & $457.66 \pm 1.50^{\mathrm{d}}$ & $565.60 \pm 1.07^{\mathrm{d}}$ & $674.08 \pm 1.94^{\mathrm{c}}$ \\
\hline $25 \%$ FWE & $473.40 \pm 1.72^{\mathrm{e}}$ & $685.42 \pm 7.51^{\mathrm{e}}$ & $747.50 \pm 1.43^{d}$ \\
\hline \multicolumn{4}{|l|}{ Protein content $(\mu \mathrm{g})$} \\
\hline Control & $2.61 \pm .03^{\mathrm{a}}$ & $2.64 \pm .07^{\mathrm{a}}$ & $3.20 \pm .03^{\mathrm{a}}$ \\
\hline $100 \%$ FWE & $1.09 \pm .02^{b}$ & $1.17 \pm .03^{b}$ & $1.07 \pm .11^{\mathrm{b}}$ \\
\hline $75 \%$ FWE & $1.16 \pm .04^{\mathrm{bd}}$ & $1.31 \pm .14^{\mathrm{b} \mathrm{d}}$ & $1.28 \pm .01^{\mathrm{c}}$ \\
\hline $50 \%$ FWE & $1.22 \pm .02^{\mathrm{cd}}$ & $1.61 \pm .05^{\mathrm{c}}$ & $2.77 \pm .02^{\mathrm{d}}$ \\
\hline $25 \% \mathrm{FWE}$ & $1.27 \pm .03^{\mathrm{c}}$ & $1.47 \pm .06^{\mathrm{cd}}$ & $2.84 \pm .02^{\mathrm{d}}$ \\
\hline
\end{tabular}

FWE: Fresh shoot water extract treatment. Figures on the same column followed by different letters show significant differences with each other at $\mathrm{p}<0.05$ according to DMRT 


\section{1) Macrothink}

Table 2a. Effect of fresh shoot water extracts (FWE) of T. rotundifolia on chlorophyll a and chlorophyll b contents of $Z$. mays

\begin{tabular}{|c|c|c|c|}
\hline Chlorophyll a $(\mu \mathrm{g} / \mathrm{g})$ & Week 1 & Wewek2 & Week 3 \\
\hline Control & $485.44 \pm 2.22^{\mathrm{a}}$ & $553.52 \pm 3.37^{\mathrm{a}}$ & $599.92 \pm 3.32^{a}$ \\
\hline $100 \%$ FWE & $301.27 \pm .70^{b}$ & $403.20 \pm 2.17^{b}$ & $499.36 \pm 2.57^{b}$ \\
\hline $75 \%$ FWE & $361.00 \pm 1.00^{\mathrm{c}}$ & $445.80 \pm 2.03^{c}$ & $554.72 \pm 4.45^{\mathrm{c}}$ \\
\hline $50 \%$ FWE & $461.20 \pm 2.80^{\mathrm{d}}$ & $497.76 \pm 2.21^{\mathrm{d}}$ & $580.14 \pm 4.11^{\mathrm{d}}$ \\
\hline $25 \%$ FWE & $497.26 \pm 2.61^{\mathrm{e}}$ & $558.34 \pm 3.51^{\mathrm{e}}$ & $560.06 \pm 5.48^{c}$ \\
\hline \multicolumn{4}{|l|}{ Chlorophyll b $(\mu \mathrm{g} / \mathrm{g})$} \\
\hline Control & $400.60 \pm .40^{\mathrm{a}}$ & $422.40 \pm 2.54^{\mathrm{a}}$ & $400.02 \pm 4.11^{\mathrm{a}}$ \\
\hline $100 \%$ FWE & $145.60 \pm .40^{b}$ & $308.48 \pm .93^{b}$ & $310.29 \pm 3.17^{b}$ \\
\hline $75 \%$ FWE & $308.60 \pm .60^{\mathrm{c}}$ & $320.80 \pm .86^{\mathrm{c}}$ & $420.00 \pm 3.16^{c}$ \\
\hline $50 \%$ FWE & $353.15 \pm 2.5^{\mathrm{d}}$ & $482.66 \pm 2.26^{\mathrm{d}}$ & $400.14 \pm 3.79^{a}$ \\
\hline $25 \% \mathrm{FWE}$ & $470.20 \pm 1.98 \mathrm{e}$ & $404.40 \pm 1.08^{\mathrm{e}}$ & $461.68 \pm 2.76^{d}$ \\
\hline
\end{tabular}

FWE: Fresh shoot water extract treatment. Figures on the same column followed by different letters show significant differences with each other at $p<0.05$ according to DMRT 
Table 2b. Effect of fresh shoot water extracts (FWE) of T. rotundifolia on total chlorophyll and protein contents of $Z$. mays

\begin{tabular}{l|l|l|l}
\hline Total Chlorophyll $(\mu \mathrm{g} / \mathrm{g})$ & Week 1 & Wewek2 & Week 3 \\
\hline Control & $867.20 \pm 2.95^{\mathrm{a}}$ & $927.60 \pm 2.50^{\mathrm{a}}$ & $987.88 \pm 3.33^{\mathrm{a}}$ \\
\hline $100 \%$ FWE & $424.00 \pm 8.46^{\mathrm{b}}$ & $720.80 \pm .66^{\mathrm{b}}$ & $730.12 \pm 3.16^{\mathrm{b}}$ \\
\hline $75 \% \mathrm{FWE}$ & $662.82 \pm 3.59^{\mathrm{c}}$ & $722.10 \pm 1.10^{\mathrm{b}}$ & $962.12 \pm 2.52^{\mathrm{c}}$ \\
\hline $50 \% \mathrm{FWE}$ & $819.40 \pm 2.80^{\mathrm{d}}$ & $942.40 \pm 5.30^{\mathrm{c}}$ & $955.20 \pm 4.14^{\mathrm{c}}$ \\
\hline $25 \% \mathrm{FWE}$ & $931.60 \pm 2.6^{\mathrm{e}}$ & $945.16 \pm 4.29^{\mathrm{c}}$ & $978.40 \pm 3.25^{\mathrm{a}}$ \\
\hline Protein content $(\mu \mathrm{g})$ & $1.05 \pm 0.03^{\mathrm{a}}$ & $1.31 \pm .02^{\mathrm{a}}$ & $1.39 \pm 0.03^{\mathrm{a}}$ \\
\hline Control & $0.49 \pm 0.01^{\mathrm{b}}$ & $0.55 \pm .03^{\mathrm{b}}$ & $0.80 \pm .03^{\mathrm{b}}$ \\
\hline $100 \%$ FWE & $0.88 \pm 0.01^{\mathrm{c}}$ & $1.25 \pm .02^{\mathrm{a}}$ & $1.38 \pm 0.09^{\mathrm{a}}$ \\
\hline $75 \%$ FWE & $0.87 \pm 0.04^{\mathrm{c}}$ & $1.34 \pm .02^{\mathrm{a}}$ & $1.56 \pm .14^{\mathrm{a}}$ \\
\hline $50 \% \mathrm{FWE}$ & $0.92 \pm 0.03^{\mathrm{c}}$ & $1.38 \pm .11^{\mathrm{a}}$ & $1.61 \pm .06^{\mathrm{a}}$ \\
\hline
\end{tabular}

FWE: Fresh shoot water extract treatment. Figures on the same column followed by different letters show significant differences with each other at $p<0.05$ according to DMRT

\section{Discussion}

Chlorophyll a, chlorophyll b and total chlorophyll contents in the shoots of $V$. unguiculata and Z. mays were inhibited by the application of the different extracts. This result correlates with the findings of some earlier workers who reported that extracts from allelopathic plants were capable of impairing chlorophyll synthesis thereby reducing chlorophyll accumulation. For example, Nitesh and Ambika (2016) reported a was significant reduction in chlorophyll contents of wheat at high concentrations of the weed extracts. Sypek et al. (2015) stated that increasing concentrations of aqueous extracts of peppermint caused a decrease of chlorophyll a and an increase of chlorophyll b content of Helianthus annuus L. According to Sonbeer et al. (2017), relative leaf water content, total leaf chlorophyll content and leaf N P K content of French bean were reduced by the aqueous extract of Jatropha. The chlorophyll content of the A. pedunculata leaves decreased with an increase in the aqueous leaf extracts concentration of the four shrubs (Wang et al., 2018) 
Yang et al. (2002) was of the opinion that allelochemicals may reduce chlorophyll accumulation in three ways namely: the inhibition of chlorophyll biosynthesis; the stimulation of chlorophyll degradation or both. The allelochemicals present in all the aqueous extracts must have inhibited chlorophyll accumulation primarily through reduction in chlorophyll synthesis or stimulation of chlorophyll degradation. A consequent reduction in net photosynthesis of the plants would be expected. That is, such inhibition of chlorophyll accumulation in the plants would be expected to naturally reduce photosynthesis and ultimately the total plant growth.

The protein contents in the shoots of $V$. unguiculata and $Z$. mays were inhibited by the application of the different extracts. The reduction in protein contents in the extract treated plants may be attributed to the effect of allelochemicals on DNA replication or transformation by intercalation with nucleic acids by ionic bonding with their negatively charged phosphate groups or the accumulation of phenolic glycine that interferes with the cytoplasmic ribosomes and production of RNA, which in turn inhibited protein synthesis (Hegab and Ghareib, 2010). Ramakrishnan et al. (2014) similarly reported that leaf leachates of Gmelina arborea inhibited protein content in green gram, red gram, black gram, and chickpea. According to Saeid (2014), there was a significant reduction in the amount of chlorophyll a, chlorophyll b, total chlorophyll, carotenoids and protein in Capsicum annuиm L. in response to allelochemical stress of aqueous leachate of Achillea biebersteinii Higher and lower concentration of extracts inhibited the protein contents in $V$. unguiculata whereas only higher concentration (100\% FWE) reduced protein contents in Z. mays compared with control. This indicated that the response of plants to allelochemicals toxicity was dependent on plant species i.e. there was an interspecific differential response to allelochemicals toxicity. This was consistent with the work of Maharjan et al. (2007) who stated that sensitivity to allelochemicals and extent of inhibition varied with species and organs of the test species.

\section{Conclusion}

The present study suggested that the aqueous extract prepared from T. rotundifolia inhibited the chlorophyll and protein contents of Vigna unguiculata (L.) Walpers and Zea mays L Therefore, the extracts contain water-soluble allelochemicals which can suppress the metabolic process of the test crops.

\section{References}

Adebowale, A., \& Olorode, O. (2005). An overview of the invasive potential of Tithonia species (Asteraceae) in Nigeria. Sci. Foc., 10(3), 65-69.

Alabi, O. Y., Odebiyi, J. A., \&. Jackai, L. E. N. (2003). Field evaluation of cowpea cultivars (Vigna unguiculata (L.) Walp.) for resistance to flower bud thrips (Megalurothrips sjostedti Trybom) Thysanoptera: Thripidae) Int. J. Pest Manag. 49(4), 287-291. https://doi.org/10.1080/0967087031000123706

Cheema, Z. A., Farooq, M., \& Wahid, A. (2013). Allelopathy: Current Trends and Future Applications Springer, Verlag. https://doi.org/10.1007/978-3-642-30595-5 


\section{Ml Macrothink}

Journal of Biology and Life Science ISSN 2157-6076 2019, Vol. 10, No. 2

Comb, J. H., Long, S. L., \& Scurlock, J. (1985). Techniques in bioproductivity and photosynthesis. Pergamon press. Oxford, New York, Toronto, Sydney Frankfurt. pp. 225-233. https://doi.org/10.3923/ijb.2010.334.342

Hegab, M. M., \&. Ghareib, H. R. (2010). Methanol extract potential of field bindweed (Convolvulus arvensis L.) for wheat growth enhancement. Int. J. Bot., 6, 334-342. https://doi.org/10.1023/A:1025634402071

Hussain, M. I., Gonzalez, L., \& Reigosa, M. J. (2010). Phytotoxic effect of allelochemicals and herbicides on photosynthesis, growth and carbon isotope discrimination in Lactuca sativa. Allelopathy Journal, 26, 157-174.

Lowry, O. H., Rosebrough, N. J., Farr, A. L., \& Randall, R. J. (1951). Protein measurement with the Folin phenol reagent. J. Biol. Chem., 193, 265-275.

Maharjan, S., Shrestha, B., \& Jha, P. K. (2007). Allelopathic Effects of Aqueous Extract of Leaves of Parthenium Hysterophorus L. on Seed Germination and Seedling Growth of Some Cultivated and Wild Herbaceous Species. Sci. World, 5(5), 33-39.

https://doi.org/10.3126/sw.v5i5.2653

Masuda, T., Polle, J. E. W., \& Melis, A. (2002). Biosynthesis and distribution of chlorophyll among the photosystem during recovery of the green algae (Dunaliella salina) from irradiance stress. Plant Physiol., 128, 603-614. https://doi.org/10.1104/pp.010595

Maysa, M. H., \& Salama, M. E. (2009). Allelopathic Effect and Oxidative Stress Induced by Aqueous Extract of Achillea Santolina L. Shoot on Triticum Aestivum L. Plant. Egypt. J. Exp. Biol. (Bot.), 5, 131-141. http://www.egyseb.net/?mno=187343 [Access: March 23, 2019]

Moussa, H. R. (2001). Physiological and biochemical studies on the herbicide (Dual) by using radiolabelled technique. Ph.D. Thesis, Faculty of Science Ain-Shams University.

Nitesh, J., \& Ambika, J. (2016) Allelopathic effects of weed extracts on germination of wheat. Ann. Pl. Sci., 5(5), 1330-1334. https://doi.org/10.21746/aps.2016.05.001

Qasem, J. R., \& Abu-Irmaileh, B. E. (1985). Allelopathic effect of Salvia syriaca L. (Syrian sage) in wheat. Weed Res., 25, 47-52. https://doi.org/10.1111/j.1365-3180.1985.tb00616.x

Ramakrishnan, M. S., Veeralakshmi, S., Sirajunnisa, A. R., \& Rajendran, R. (2014). Effect of Allelochemicals from Leaf Leachates of Gmelina arborea on Inhibition of Some Essential Seed Germination Enzymes in Green Gram, Red Gram, Black Gram, and Chickpea, Int. Sch. Res Notices.

Saeid, A. (2014). Allelopathic Potential of Achillea biebersteinii Afan. (Asteraceae) World Appl. Sci. J., 15(7), 947-952.

https://pdfs.semanticscholar.org/b0cf/1c0cb641805d6f7b0c349701d6c784d7b7b2.pdf23/03/1 $93.13 \mathrm{pm}$

Saeid, A., Mohammad, S., \& Rida, S. (2010). Allelopathic effects of spurge (Euphorbia hierosolymitana) on wheat (Triticum durum). Eurasian J. Agric. Environ. Sci., 7, 298-302. 


\section{Macrothink

Siyar, S., Chaudhry, Z., \& Majeed, A. (2017). Comparative Phytotoxicity of Aqueous Extracts of Centaurea Maculosa and Melilotus Officinalis on Germinability and Growth of Wheat. Cercetări Agronomice In Moldova, 1(4), 29-35. https://doi.org/10.1515/cerce-2017-0033

Sonbeer, C., Kaushik, D., Prakash, K., Bhoutekar, S., \& Lal, N. (2017). Effect of Different Doses of Jatropha Leaf Extract on Growth and Development of French Bean (Phaseolus vulgaris L.) and Brinjal (Solanum melongena). Int.J.Curr.Microbiol.App.Sci., 6(5), 2692-2705. https://doi.org/10.20546/ijcmas.2017.605.302

Sypek, E., Repka, P., Stachurska-Swakoń, A., Barabasz-Krasny, B., \& Możdżeń, K. (2015). Allelopathic Effect of Aqueous Extracts from the Leaves of Peppermint (Mentha piperita L.) on Selected Physiological Processes of Common Sunflower (Helianthus annuus L.) Bot Horti Agrobo, 43(2), 335-342. https://doi.org/10.15835/nbha.43.2.10034

Tongma, S., Katsuichiro, K., \& Kenji, U. (1998). Allelopathic activity of Mexican sunflower (Tithonia diversifolia) in soil. Weed Sci. 46(4), 432-437.

https://doi.org/10.1017/S0043174500090858

Wang, X., Wang, J., Zhang, R., Huang, Y., Feng, S., Ma, X., Zhang, Y., Sikdar, A., \& Roy, R. (2018). Allelopathic Effects of Aqueous Leaf Extracts from Four Shrub Species on Seed Germination and Initial Growth of Amygdalus pedunculata Pall. Forests, 9, 711.

https://doi.org/10.3390/f9110711

Yang, C. M., Lee, C. N., \& Chou, C. H. (2002). Allelopathic phenolics and chlorophyll accumulation: Effect of three allelopathic phenolics on chlorophyll accumulation of rice (Oryza sativa) seedlings: 1. Inhibition of supply - orientation. Botanical Bulletin of Academia Sinica, 43, 299-304.

https://ejournal.sinica.edu.tw/bbas/content/2002/4/bot434-07.html

Zarnota, M. A., Rimando, A. M., \&. Weston, L. A. (2003). Evaluation of root exudates of seven sorghum accessions. J. Chem. Ecol. 29, 2073-2083.

https://doi.org/10.1023/A:1025634402071

Zeng, R. S., Mallik, A. A. U., \& Luo, S. M. (2008). Allelopathy in Sustainable Agriculture and Forestry Springer, New York, USA. https://doi.org/10.1007/978-0-387-77337-7

\section{Copyright Disclaimer}

Copyright for this article is retained by the author(s), with first publication rights granted to the journal.

This is an open-access article distributed under the terms and conditions of the Creative Commons Attribution license (http://creativecommons.org/licenses/by/3.0/). 